\title{
PÓLYA TYPE INTEGRAL INEQUALITIES: ORIGIN, VARIANTS, PROOFS, REFINEMENTS, GENERALIZATIONS, EQUIVALENCES, AND APPLICATIONS
}

\author{
FENG QI
}

\begin{abstract}
In the article, the author gets to the bottom of the origin of Pólya's integral inequality, plots out the development of the theory of inequalities, collects variants and proofs of Pólya's integral inequality, surveys Iyengar-Mahajani's, Agarwal-Dragomir's, Cerone-Dragomir's, and Qi's refinements, generalizations, and applications of Pólya's integral inequality, and find equivalences between these integral inequalities.
\end{abstract}

Mathematics subject classification (2010): Primary 26D15; Secondary 33C75, 33E05, 41A55.

Keywords and phrases: Pólya's integral inequality, Iyengar-Mahajani's integral inequality, AgarwalCerone-Dragomir's integral inequality, Qi's integral inequality, equivalent relation, Steffensen's inequality, Hayashi's integral inequality, Rolle's mean value theorem, Lagrange's mean value theorem, Taylor's mean value theorem with Lagrange's remainder, convex function, mean, complete elliptic integral, geometric proof, analytic proof, history, journal.

\section{REFERENCES}

[1] R. P. Agarwal And S. S. DRAgomir, An application of Hayashi inequality for differentiable functions, Computers Math. Appl. 32 (1996), no. 6, 95-99; Available online at http://dx.doi.org/10.1016/0898-1221 (96)00146-0.

[2] R. P. Agarwal, V. ČUlJak, AND J. E. PeČARIĆ, Some integral inequalities involving bounded higher order derivatives, Math. Comput. Modelling 28 (1998), no. 3, 51-57; Available online at http://dx.doi.org/10.1016/S0895-7177(98)00098-3.

[3] P. S. Bullen, Handbook of Means and Their Inequalities, Mathematics and its Applications, Volume 560, Kluwer Academic Publishers, Dordrecht/Boston/London, 2003.

[4] P. Cerone, Generalised trapezoidal rules with error involving bounds of the $n$-th derivative, Math. Inequal. Appl. 5 (2002), no. 3, 451-462; Available online at http://dx.doi.org/10.7153/ mia-05-44.

[5] P. CERONE AND S. S. DRAGOMIR, Lobatto type quadrature rules for functions with bounded derivative, Math. Inequal. Appl. 3 (2000), no. 2, 197-209; Available online at http://dx.doi.org/ $10.7153 / \mathrm{mia}-03-23$.

[6] V. ČUlJaK AND N. Elezović, A note on Steffensen and Iyengar inequality, Glas. Mat. Ser. III 33 (53) (1998), no. 2, 167-171.

[7] Department of Mathematics, East China Normal University, Mathematical Analysis, 3rd ed., Higher Education Press, Beijing, China, June 2001. (Chinese)

[8] S. S. Dragomir, Y. J. Cho, AND S. S. Kim, Some remarks on Milovanović-Pečarić inequality and applications for special means and numerical integrations, Tamkang J. Math. 30 (1999), no. 3, 203-211; Available online at http://dx.doi.org/10.5556/j.tkjm.30.1999.203-211.

[9] S. S. Dragomir and C. E. M. Pearce, Selected Topics on Hermite-Hadamard Type Inequalities and Applications, RGMIA Monographs, Victoria University, 2000; Available online at http://rgmia.org/monographs/hermite_hadamard.html. 
[10] S. S. DRAGOMIR AND S. WANG, Applications of Iyengar type inequalities to the estimation of error bounds for the trapezoidal quadrature rule, Tamkang J. Math. 29 (1998), no. 1, 55-58; Available online at http://dx.doi.org/10.5556/j.tkjm.29.1998.55-58.

[11] N. Elezović And J. E. PEČARIĆ, Steffensen inequality and estimates of error in trapezoidal rule, Appl. Math. Lett. 11 (1998), no. 6, 63-69; Available online at http://dx.doi.org/10.1016/ S0893-9659(98)00104-9.

[12] A. M. Fink, An essay on the history of inequalities, J. Math. Anal. Appl. 249 (2000), 118-134; Available online at http://dx.doi.org/10.1006/jmaa.2000.6934.

[13] B.-N. GUO AND F. QI, A simple proof of logarithmic convexity of extended mean values, Numer. Algorithms 52 (2009), no. 1, 89-92; Available online at http://dx.doi.org/10.1007/ s11075-008-9259-7.

[14] B.-N. Guo And F. QI, Proofs of an integral inequality, Mathematics and Informatics Quarterly 7 (1997), no. 4, 182-184.

[15] B.-N. GUo AND F. QI, Some bounds for the complete elliptic integrals of the first and second kinds, Math. Inequal. Appl. 14 (2011), no. 2, 323-334; Available online at http://dx.doi.org/ 10.7153/mia-14-26.

[16] B.-N. GUO AND F. QI, The function $\left(b^{x}-a^{x}\right) / x:$ Logarithmic convexity and applications to extended mean values, Filomat 25 (2011), no. 4, 63-73; Available online at http://dx.doi.org/ 10.2298/FIL1104063G.

[17] G. H. Hardy, J. E. Littlewood, and G. Pólya, Inequalities, Cambridge University Press, 1934.

[18] T. HAYASHI, On curves with monotonous curvature, Tôhoku Math. J. 15 (1919), 236-239.

[19] K. S. K. IYENGAR, Note on an inequality, Math. Student 6 (1938), 75-76.

[20] P. K. Menon, Some integral inequalities, Math. Student 11 (1943), 36-38.

[21] G. Klambauer, Mathematical Analysis, Pure and Applied Mathematics Series 31, Marcel Dekker, New York, 1975. Chinese Edition, translated by Ben-Wang Sun, Hunan People Press, Changsha City, 1981.

[22] G. Klambauer, Problems and Propositions in Analysis, Lecture Notes in Pure and Applied Mathematics 49, Marcel Dekker, New York and Basel, 1979.

[23] J.-C. KuAng, Chángyòng Bùděng Shì (Applied Inequalities), Hunan Education Press, Changsha City, Hunan Province, China, 1989. (Chinese)

[24] J.-C. KuAnG, Chángyòng Bùděng Shì (Applied Inequalities), 2nd ed., Hunan Education Press, Changsha City, Hunan Province, China, 1993. (Chinese)

[25] J.-C. KuAng, Chángyòng Bùděng Shì (Applied Inequalities), 3rd ed., Shandong Science and Technology Press, Ji'nan City, Shandong Province, China, 2004. (Chinese)

[26] Z. LIU AND Y.-X. SHI, Note on Iyengar type integral inequalities, J. Anshan Univ. Sci. Tech. 26 (2003), no. 4, 318-320. (Chinese)

[27] Z.-F. Lu, Gāoděng Shùxué Jiěxū Dàquán, Liaoning Science and Technology Press, Shenyang City, China, 1991. (Chinese)

[28] G. S. Mahajani, A note on an inequality, Math. Student 6 (1938), 125-128.

[29] M. MATiĆ, J. E. PEČARIĆ, AND N. UjeviĆ, On new estimation of the remainder in generalised Taylor formula, Math. Inequal. Appl. 2 (1999), no. 3, 343-361; Available online at http://dx.doi.org/10.7153/mia-02-31.

[30] G. V. Milovanović And J. E. Pečarić, Some considerations on Iyengar inequality and some related applications, Univ. Beograd. Publ. Elektrotehn. Fak. Ser. Mat. Fiz. 544-576 (1976), 166-170.

[31] D. S. Mitrinović, Analytic Inequalities, Springer, New York-Heidelberg-Berlin, 1970.

[32] D. S. Mitrinović, Analytic Inequalities, Chinese Ed., Translated by X.-P. Zhang and L. Wang, Science Press, Beijing, 1987.

[33] D. S. Mitrinović, J. E. Pečarić, And A. M. Fink, Classical and New Inequalities in Analysis, Kluwer Academic Publishers, 1993.

[34] C. P. Niculescu And L.-E. Persson, Convex Functions and their Applications, CMS Books in Mathematics, Springer-Verlag, 2005.

[35] G. PóLYA, Ein mittelwertsatz für Funktionen mehrerer Veränderlichen, Tôhoku Math. J. 19 (1921), $1-3$.

[36] G. Pólya And G. Szegö, Aufgaben und Lehrsätze aus der Analysis, Volume I, Springer-Verlag, Berlin, 1925. (German) 
[37] G. Pólya And G. Szegö, Problems and Theorems in Analysis, Volume I, Classics in Mathematics, Springer-Verlag, Berlin, 1998.

[38] G. Pólya AND G. SzEgö, Problems and Theorems in Analysis, Volume I, Chinese Edition, 1984.

[39] F. QI, Inequalities for an integral, Math. Gaz. 80 (1996), no. 488, 376-377; Available online at http://dx.doi.org/10.2307/3619581.

[40] F. QI, Pólya type integral inequalities: Origin, variants, proofs, refinements, generalizations, equivalences, and applications, RGMIA Res. Rep. Coll. 16 (2013), Art. 20, 32 pages; Available online at http://rgmia.org/papers/v16/v16a20.pdf.

[41] F. QI, Z.-L. WEI, AND Q. YANG, Generalizations and refinements of Hermite-Hadamard's inequality, Rocky Mountain J. Math. 35 (2005), no. 1, 235-251; Available online at http://dx. doi.org/ 10.1216/rmjm/1181069779.

[42] J. F. STEFFENSEN, On certain inequalities between mean values, and their application to actuarial problems, Scandinavisk Aktuarietidskrift (1918), 82-97.

[43] J. F. STEFFENSEN, On certain inequalities and methods of approximation, Scandinavisk Aktuarietidskrift (1919), 274-297.

[44] Y. SUn, H.-T. YANG, AND F. QI, Some inequalities for multiple integrals on the $n$-dimensional ellipsoid, spherical shell, and ball, Abstr. Appl. Anal. 2013 (2013), Article ID 904721, 8 pages; Available online at http://dx.doi.org/10.1155/2013/904721.

[45] P. M. Vasić And G. V. Milonanović, On an inequality of Iyengar, Univ. Beograd. Publ. Elektrotehn. Fak. Ser. Mat. Fiz. 544-576 (1976), 18-24.

[46] P. M. VASIĆ AND J. E. PeČArić, Note on the Steffensen inequality, Univ. Beograd. Publ. Elektrotechn. Fak. Ser. Mat. Fiz. 716-734 (1981), 80-81.

[47] L.-Z. Xu AND X.-H. WANG, Shùxué Fénxī Zhōng de Fāngfă hé Liť̌ Xuănjiăng (Selected Methods and Examples of Mathematical Analysis), Rev. Ed., Higher Education Press, Beijing, China, 1983. (Chinese)

[48] L. Yin AND F. QI, Some inequalities for complete elliptic integrals, Available online at http://arxiv.org/abs/1301.4385. 